\title{
THE ROLE OF THE RUSSIAN LANGUAGE IN INDIA'S HEALTHCARE SECTOR
}

\author{
Neelakshi Suryanarayan \\ University of Delhi \\ Delhi University, 110007 Delhi, India
}

\begin{abstract}
The last few years have seen the influx of a new kind of tourist to India - medical tourists, coming in search of good quality and affordable treatments for a variety of medical procedures. With a large number of patients coming from Russia and countries of the former Soviet Union, the demand for local people with knowledge of Russian is steadily rising. Through ethnographic field work, which includes participant observations and interviews, this paper traces the development of the use of Russian in large private hospitals in Delhi, which have started attracting patients from the former Soviet Republics for medical services. The aim of the present paper is to introduce a pilot study of a relatively new sphere of economic activity where commodification of Russian language is acquiring a prominent place in India. My goal is to examine how Russian provides an added value to these hospitals in terms of the clientele they attract and how well it works for the clients themselves. In addressing these issues the paper aims to reveal the specific conditions and processes that characterize the use of Russian in 'medical tourism' in India and the motivation of the personnel involved. The results of the study indicate that commodification of the Russian language in India is an expanding phenomenon.
\end{abstract}

Keywords: medical tourism, India, commodification, Russian language, language workers

\section{INTRODUCTION}

"I am currently studying Russian and in the future I also plan to study Croatian and Bulgarian languages. With the increasing prices of medical surgeries in the Western World, patients are turning to India for their treatment. This is especially true in the case of those living in parts of Eastern Europe and Africa, where certain medical procedures even when available are incredibly expensive."

This excerpt from a conversation with a student of Russian at a University in Delhi recently published in an Indian newspaper highlights the link between transnational healthcare and language as much as it shows how the Indian healthcare industry has become an expression of a service industry that extends beyond national borders and that aims to attract patients on a global scale. Indeed, within the last two decades, India's private medical sector entered the world's healthcare market, offering medical treatment at an international level at costs that were and still are well below the average treatment costs for medical procedures in most countries (Crooks et al 2011). This continues to be attractive for patients from regions where certain medical treatments are not available, are too costly, or where local healthcare providers are underfunded and where little trust exist in medical treatment and the medical profession as a whole. However, what the excerpt at the beginning also shows is that apart from hospitals who capitalize on patients, medical tourism to India (and elsewhere) entails more than just medical treatment and 
medical staff caring for you. Here, apart from healthcare brokers who mediate between Indian hospitals and prospective patients and help in organizational matters including accommodation, visa, transfers and in some cases touristic programs (Babu and Anjaneya Swamy 2007), interpreters who are able to communicate in the language of patients hold a key position within this movement of patients across national borders (Connell 2015). Because of the need of patients to communicate with medical workers at hospitals, interpreting services and any other communication prior, during and after medical treatment in the patient's language of choice may evolve into a marketing argument that can be utilized in promotional discourses by healthcare providers in medical tourism markets and that as such may even provide an added value to the medical services offered (Muth 2017). This extends to not only languages spoken in neighboring countries, to English as a global language, but can also relate unexpectedly - within particular national and geographic contexts - to other not widely available communicational resources such as Russian in India.

Hence, it is the purpose of this paper to examine the role and relevance of Russian language workers and medical interpreters in private hospitals in and around the country's capital Delhi with the help of ethnographic research. Drawing insights from participant observations, structured- and semi-structured interviews as well as questionnaires, this paper asks if and to what extent Russian is becoming a commodity, meaning a language that provides an added value to healthcare services offered on post-Soviet markets. Furthermore, this study intends to examine the conditions of interpreting work for Russian-speaking patients as well as the consequences the marketization and valorization of Russian has. In essentially viewing them from four interrelated perspectives that include (1) hospital administration staff, (2) patients, (3) medical doctors, and (4) interpreters and language workers, this paper will highlight what is at stake for whom in efforts to capitalize on particular linguistic resources within India's medical tourism industry.

In the following, I will first outline the theoretical foundation of this research, discuss the role of Russian in independent India, and highlight the positioning of medical tourism as an expression of the globally operating neoliberal healthcare industry in India and beyond. This is followed by a brief description of the paper's methodological approach and research questions, before analyzing ethnographic data from four hospitals in the Delhi metropolitan area this research draws from.

\section{LANGUAGE, GLOBALIZATION AND COMMODIFICATION: SETTING THE SCENE}

In the past few years there has been an increase in research addressing the impact of globalization and liberalization on language, cross-cultural communication, multiculturalism, bilingualism and commodification of language. In particular, research on the commodification of language establishes connections between the valorization of communicative resources and neoliberal economic ideologies, globalization and the rise of service industries within late capitalism (Rubdy and Tan 2008; Duchêne and Heller 2012; Heller 2003; Heller 2011)). As Coulmas (2005) highlights, marketization, deregulation and participation are the major components of present-day globalization, and "in- 
creasing interdependence and electronic communications that facilitate the exchange of information among individuals, organizations and societies are vital parts of this process, leading to language borrowing, neologisms, dual language phrases and commodification. More importantly, Coulmas explores how globalization and language interact and, more specifically, how language regimes change under the influence of economic, political and cultural developments. Stressing the centrality of language, and, in particular, linguistic variability and multilingualism, as a core feature of late capitalism (Harvey 1989), Heller and Duchêne (2012) highlight the role of language in society and economy within current political-economic conditions. Within the context of economic tertiarization and now globally operating service industries, for them, communicative resources can mean an added value to a particular product or service. Referring to language as an economic resource, this results in the rise of language industries that exploit multilingual speakers (such as call centers), or that strategically employ speakers of particular languages for market expansion to add value to a particular service (such as interpreting in medical tourism). In line with the opening up of hitherto closed national economies and an increasing individual mobility, providing the 'right' communicative resources for certain markets thus emerge as distinctive properties that promise market expansion and capital gain.

Hence, Heller (2010) focuses on the ways in which language plays a central role in the new globalized economy, due to its centrality both as a means of production and as a product. The nature and role of communication, the rise of services industries, and increasing global economic integration have made language part of work-related competence, either as a measurable skill or as way to add value to a product or service, for instance by offering it in a particular language that at a given moment in time promises to be useful in order to attract consumers from certain markets. This also highlights a link to the market value of authenticity, in an economy where local and regional markets and local authenticity - are sources of value, and what the implications of these developments might be for the emerging category of language workers. Since healthcare is part of the larger services sector, which is culturally specific and language dependent the importance of cross-cultural and cross-linguistic expertise is at a premium. Specifically referring to the commodification of Russian in the globalized world, Pavlenko (2017; this issue) and Muth (2017a) look at the post-Soviet space and context as a natural sociolinguistic experiment for commodification. The collapse of an entire way of life and the general void in the socio-cultural and economic environment provides fertile soil and makes a significant contribution to an understanding of how languages become imbued with value and are utilized as commodities in various fields within the service- and tourism economy. This research highlights that the significant growth of the Russian economy and its opening up to the rest of the world in the late 1990s led to commodification of Russian in a number of contexts both within and beyond the former Soviet Union. With regard to the commodification of Russian beyond post-Soviet spaces, language skills in Russian mean an added value to the products of many service providers, ranging from healthcare to conventional tourism, from restaurants having menus in Russian readily available to hospitals providing interpreting services and care work in the language of Russian-speaking patients (Muth 2017a; Pavlenko 2017; Suryanarayan 2017). 


\section{RUSSIAN IN INDIA}

The foundations for any efforts to draw additional value from Russian as a communicative resource in India can be traced back to the 1950s as a result of the ties that newly-independent India was forging with the Soviet Union. Within the early years of Independent India, the Soviet model of economic development, emphasizing state control of key industries gained popularity (Sahai 1990). This was further underscored in 1971 through the twenty-year treaty of peace, friendship and cooperation between India and the Soviet Union. India benefitted from Soviet technical assistance and development aid, while the Soviet Union sought a strategic partner within South Asia (Ollapally 2002). Many development projects were implemented with the help of Soviet experts who worked in various parts of India. What started as a political initiative for economic growth had its impact on the use of Russian language in India. The first Department of Russian Language was set up at the University of Delhi. Soon, departments of Russian language were established in universities throughout the country. There was an urgent need for people with knowledge of Russian to work in various economic sectors - defense, navy, steel plants, as well as the exploitation of India's natural resources, in particular oil and gas. After the collapse of the Soviet Union, Russian speaking visitors from post-Soviet countries travelled to the country as traders and shopping tourists while since the early 2000s, ties between India and the Russian Federation once again intensified (Pant 2013), in turn raising the prestige of Russian in the country. Many private travel agencies began catering to Russian tourists with special offers and itineraries and continue to this day, primarily focusing on shopping tourism as well as more recently - transnational healthcare and the movement of Russian-speaking patients to the country (Crooks et al. 2011).

\section{MEDICAL TOURISM TO INDIA AND BEYOND: RUSSIAN-SPEAKING PATIENTS ON THE MOVE}

Russian speaking medical tourists travelling to India are neither a unique nor a solitary phenomenon. International travel for medical purposes is increasingly common in many other parts of the world. Shopping abroad for medical care is not a new trend, yet despite being an expression of luxury and entitlement (Connell 2015), it may also become a necessity especially when patients are faced with unreliable, strained or expensive healthcare systems in their countries of origin. The Chinese have been heading to South Korea for cosmetic surgery, Germans for spa treatments and dental care to Hungary at considerably lower costs, Iraqis to Lebanon for essential medical procedures not anymore available in their home country, while North Americans have long traveled to Latin American destinations like Argentina or Brazil to undergo cosmetic surgeries that are not covered by their insurance policies (Chuang et al. 2014; Connell 2015; Jones and Keith 2006; Viladrich and Baron-Faust 2011). Yet to cross national borders for the treatment of serious medical conditions as a mass phenomenon is more recent and is emblematic of a trend stemming from a necessity for medical care that cannot be accessed at home because of lacking or inadequate medical infrastructure, high out of pocket medical costs as well as rising insurance premiums that prompt patients to seek treatment elsewhere (Milstein and Smith 2006). Hence, in recent years a number 
of countries have emerged as healthcare destinations with highly stratified patient groups, among them Germany, Hungary, Israel, Japan, Lebanon, Lithuania, Malaysia, Mexico, Singapore, South Africa, South Korea, Switzerland, Thailand, Turkey, as well as the United Kingdom (Chuang et al. 2014; Connell 2013; 2015). In recent years, India became a stakeholder in this industry as well, promising comprehensive care at a worldclass care level and with affordable prices (Crooks et al. 2011).

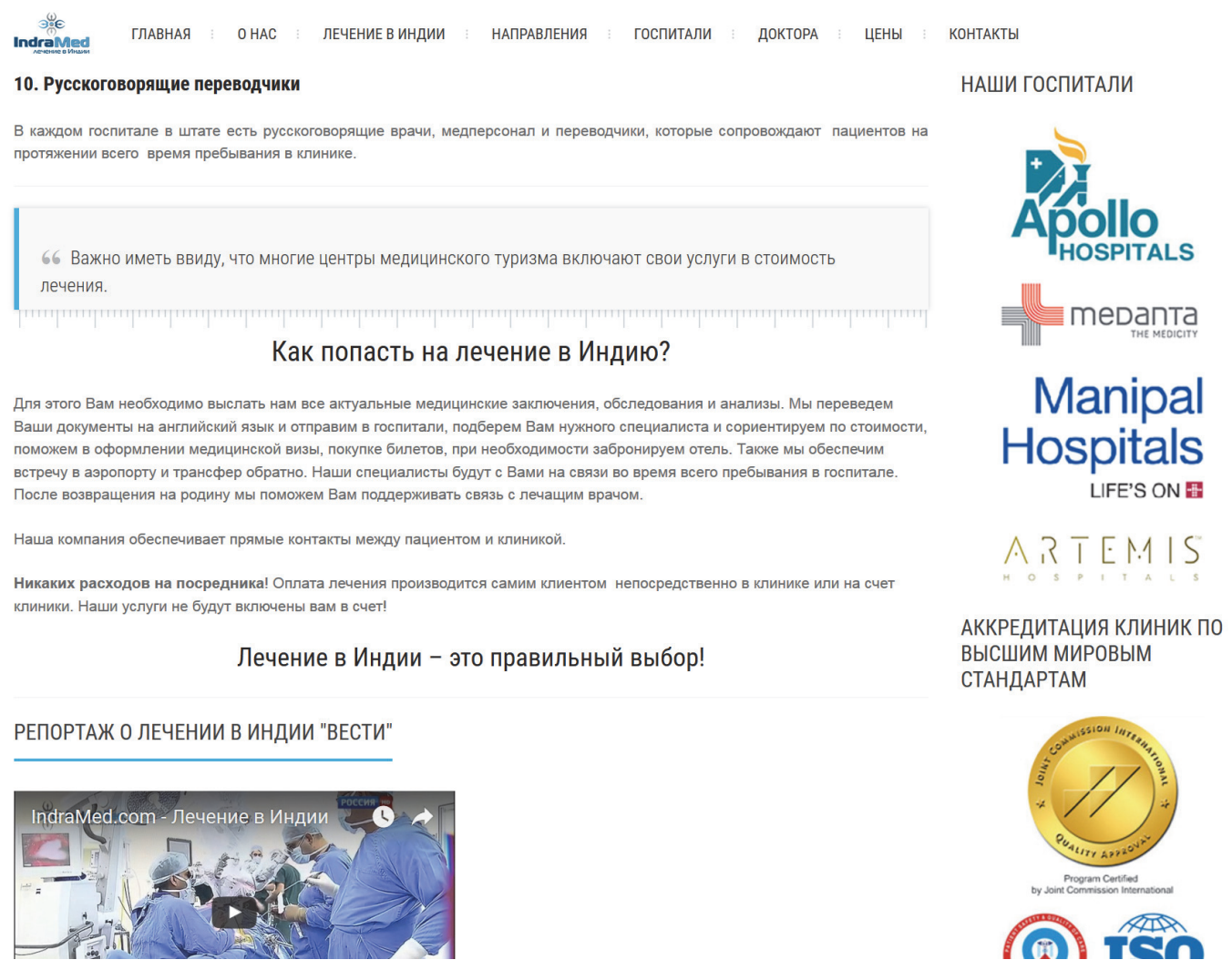

Image 1. Screenshot of a website of a healthcare broker based in Delhi, India aimed at Russian-speaking medical tourists from post-Soviet countries

Following the collapse of the USSR, healthcare systems in all former Soviet countries and in Russia in particular underwent dramatic changes and restructuring. As state support was withdrawn and healthcare oftentimes became privatized, vast gaps appeared in the quality of care, the services of the doctors as well as overall costs for individual patients. This resulted in many Russian-speaking patients seeking treatment elsewhere, within the last two decades primarily in Germany, Israel, Lithuania, or Turkey (Muth 2017a; 2017b). Yet in recent years Russian-speaking patients mainly from Russia, Kazakhstan and Uzbekistan were beginning to travel to India that, while still being a developing country, increasingly possesses pockets of excellence in the health care industry, most notably around the agglomerations of Delhi and Mumbai (Babu et al. 2007; Crooks et al. 2011). There are sizable numbers of qualified doctors and specialists, professional and competent nursing staff and a number of world class hospitals and health 
care facilities. At the same time, due to low labour costs, treatment costs in India compare very favorably with those in advanced industrialized countries and as such increasingly attract middle- and lower-middle class patients from both industrialized and developing countries.

The quality and affordability of healthcare in premier Indian hospitals, together with the fact that India is relatively a short flight away from several post-Soviet successor states, led to influx of thousands of Russian-speaking patients in India starting around a decade ago. Russian may not be the native language of some of these tourists, yet it is the lingua franca of the region and a proficient second language of many people whose English-language skills are negligible or non-existent (Muth 2017a; 2017b). The demand for service in Russian created conditions calling for language workers, with expertise in healthcare interpreting and translation. Effective, timely and accurate communication between doctors and patients is vital for efficient medical treatment, as is the assurance to patients that they will be linguistically accommodated during their stay which becomes a vital marketing argument. Miscommunication between doctors and patients increases the chances of wrong diagnosis, faulty treatments, and post-operative complications. The results can sometimes be catastrophic. Kaspar (2015) highlights this with regard to the Indian context, noting that "[...] the vital role of good communication in health care is commonly acknowledged - and so is its complexity and difficulty". In line with this argumentation, the organization of care for international patients entails the availability of language workers as intermediaries between professionals and patients, encompassing the planning of treatment, how this is communicated to patients, as well as interactions with medical staff at the hospital. Furthermore, and in relation to the potential commodity value of communicative resources and how those are understood and valued by prospective patients, promotional discourses such as advertising campaigns or websites of both healthcare providers and brokers are equally central aspects that describe the relationship between language and medical tourism.

Medical tourism from post-Soviet countries and patient flows of Russian-speakers to Delhi hospitals clearly demonstrates how the Russian language has acquired a new value in this area and is being used as commodity. In fact, the last few years have seen an increase in the number of students taking admission in part-time courses in Russian language. And more and more students studying different languages are turning to medical tourism as an avenue for them to use their skills.

\section{RESEARCH DESIGN AND METHODOLOGY}

This study intends to examine several aspects of medical tourism in India connected to Russian, focusing on the Delhi metropolitan area. In particular this research aims to answer the following questions:

What is the role and relevance of Russian language workers in private hospitals in Delhi? Does Russian become a language that provides an added value to healthcare services offered on Russian-speaking markets?

What is the nature of relationship between patients/doctors/administrative staff and language workers?

What are the conditions of work for those providing interpreting services to Russianspeaking patients? 
For the purpose of this study I identified four prominent private hospitals in Delhi and its vicinity which have been attracting patients from Russia and countries of the post-Soviet sphere, most notably Kazakhstan, Tajikistan and Uzbekistan. These hospitals promise to provide state of the art services in medical care for the local Indians and along with that have set up 'International Sections' to cater to the large number of patients, who, apart from countries of the former Soviet Union mainly come from the developing world such as Afghanistan, Iraq, Ethiopia, Nigeria, Sudan (Crooks et al. 2011). Recently, also patients from Japan, the US and other developed nations started to seek treatment at those hospitals.

Four sets of informants who are directly involved in the mobility of Russianspeaking medical tourists participated in this study (in this case patients requiring the use of Russian language in clinical interactions). Those informants include (1) hospital administration staff, (2) patients, (3) medical doctors, as well as (4) interpreters and language workers. As ethnography of language work in Russian within private healthcare providers in India, the study relies on questionnaires in English, structured and semistructured interviews both in English and Hindi, and participant observation that were gathered over a period of several months in 2015 and 2016. Patients and doctors were interviewed as and when they gave their consent. However, it was very difficult to get sufficient time for interviews with doctors working at the hospitals, largely because of their extremely busy schedule. Conversations were recorded digitally with the permission of the interlocutors; however, when not allowed, detailed field notes were taken in writing.

\section{DISCUSSION}

(1) In our research, the hospital administration is represented by the hospitals' human resource departments (hereafter HR). Representatives from the HR teams of the four hospitals responded to a questionnaire in English which contained - among others the following sets of questions. These were chosen in order to better understand the role and relevance of Russian language workers within the four hospitals:

Since when have you started employing the services of Russian speaking personnel?

How many employees do you have at the present moment? What is the selection process? What is the minimum educational qualification you demand?

Do you have a feed — back system to evaluate their performance/knowledge of Russian? What is that?

From which countries are the patients who are using the services of these Russian language interpreters? How many patients needing the use of these interpreters do you have on an average in a month?

Do you provide any other services for these patients, for example providing or organizing accommodation for relatives of patients?

Do you think the demand for Russian language interpreters will increase or decrease in the future? For which other language have you employed interpreters? Do you think the interpreters need more specialised training in this field?

Have there been any cases of miscommunication or incorrect information that the patients have reported to you? How do you deal with an inefficient interpreter? 
The HR departments' answers revealed that the hospitals started employing the services of Russian speaking personnel at the hospitals' mainly since 2009 when they found the need to give special attention to those patients who required interpreting services and accommodation in the language of their choice. All of the four hospitals have at least two to three interpreters directly employed by the hospital, yet in addition to that they also employ the services of freelance language workers in case demand increases above the usual. The freelance interpreters are provided through an agent who is in regular contact with the hospital. These hospitals get an average of about a 100 to 150 patients per month who require the services of interpreters. The patients enter the hospitals for various treatments, out of which oncology is the most common. The hospitals employ language specialists who at least hold a diploma in Russian. They get selected after going through an interview. The hospitals do not advertise these posts and have been selecting the specialists through recommendation by others. The hospital authorities claim that they take regular feedback about the performance of the language specialists from the patients and have received only very few complaints of miscommunication or incorrect information. None of the hospitals in the present survey have terminated the services of any interpreter so far. All hospital representatives in HR agreed that the interpreters need specialized training in the area of medical terminology and that the implementation of special courses for this purpose would be very beneficial. All were convinced that medical travel from Russian-speaking countries is a very fast growing market and is likely to grow exponentially.

(2) The patients constitute a group of informants that helps us to learn about the countries of origin, their linguistic resources and that furthermore may help to better understand why Russian-speaking patients chose India as a healthcare destination. For that, I was able to talk to a number of patients and their attendants and inquire about their trajectory. They came from three Central Asian countries where Russian is a language of wider communication, Uzbekistan, Tajikistan and Kazakhstan. All patients agreed that second to the question about the expertise of the doctor over a particular treatment and the reputation of the hospital, the interpreter service available to them in the hospital was a very important factor in helping them to decide to come to a particular hospital, highlighting that in healthcare particular communicative resources may indeed provide an added value that goes beyond medical services (Muth 2017a). However, some patients acknowledged that they would have come for treatment to a certain hospital irrespective of the availability of an interpreter, but in that case they would have brought an interpreter with them from their home country, which would have meant additional costs. In interviews, all patients stated that they came to India either because the particular medical service they required was not available in their home country or because there was a long waitlist for procedures, or because it was more expensive than in their country of origin. Many chose a particular hospital because they learnt of it by word of mouth, through another friend or relative who had been treated here, or through an agent.

Regarding language work and interpreting services, all patients stated that they were happy with the services of the interpreters. They highlighted, that sometimes miscommunication occurred, but in case this had happened, it was soon rectified and the pa- 
tients were not offended. All patients expressed the need for more language specialists, because, when they had to share the services of the specialist interpreter with other patients, they were compelled to wait for his/her help. All patients praised the work of the language specialists and interpreters, highlighting their kindness, polite behavior as well as their flexibility and willingness to be available all the time. Some of the patients enlisted the help of their interpreters outside the hospital working hours for shopping and sightseeing activities. As for the level of proficiency in Russian, the responses proved to be very varied. While some patients said that the interpreters were competent, others were of the opinion that there was a lot of scope for improvement. One patient, who had been in the hospital for over a month said that the interpreter assigned to her was shy and lacked confidence in the beginning, but picked up the skills slowly, in about a month. Another patient said that it was essential to have language specialists with good knowledge of medical procedures and terms. When asked if the hospital staff approached them for a feedback of the quality of the interpreters, they replied, no such formal system for an appraisal by the patients existed except in one hospital, raising questions in regard to both the actual quality of interpreting services as well as the overall conditions of work of healthcare interpreters in the country.

(3) As previously mentioned, doctors were the least accessible group of informants, largely because of their tight schedules that made it difficult to obtain appointments with them. Brief conversations were only possible with two of them from one of the four hospitals. They showed an understanding for the importance of interpreting services, but since most language workers lacked any background in medicine, the doctors found it difficult to convey particular vital issues concerning patients' medical treatment. In certain delicate cases, the doctors found counseling patients through an interpreter challenging. One of the informants repeatedly expressed concerns that doctor-patient interactions were not being correctly transmitted by interpreters.

(4) Interpreters and language workers constitute a vital link between the patient and medical staff at the hospital. In case patients lack even basic skills in a language expected to be understood by hospital workers (for instance English), they literally provide a lifeline for the patient who is not only coping with the trauma of having a potentially life-threatening medical condition but who is also adjusting to an alien country and a new culture.

Eighteen Russian language specialists who were attached to the four hospitals were interviewed. They were also asked to answer a questionnaire which contained enquiries pertaining to their educational qualifications, length of time spent in learning Russian, name of the institution where they learned Russian, current employment situation, working hours per day, as well as occupational status (permanent, temporary or a freelance/ self-employed). In addition to those, I asked the following sets of questions:

How did you learn about this line of work? For how many patients do you work on an average per day? Do you receive any overtime remuneration? Do you provide any other services for these patients, for example providing or organizing accommodation for relatives of patients?

Do you think the demand for Russian language interpreters will increase or decrease in the future? 
Do you have some prior medical knowledge and how long did it take you to get accustomed to medical interpreting? Does your employer appraise your Russian skills in some form? Do patients provide feedback about the quality of your work? How do you cope with miscommunication or lack of understanding?

Are you satisfied with your work and the work environment, how do you see the future of this profession and your own future? Would you attend a specialized course in Russian for medical purposes even if it would mean additional costs?

Fourteen out of the eighteen interpreters interviewed were postgraduates in Russian philology, from either Delhi University or Jawaharlal Nehru University, the two large universities in Delhi where Russian is taught at undergraduate (Bachelor) and post-graduate (Masters) level. Four were diploma holders who had studied Russian for a year or even less. Most of informants started working in this profession only since 2010 while some were very recent recruits. Three of them started working while studying at the university after hearing about the need for Russian speakers in one particular hospital. The remaining informants were introduced to the hospital through their classmates at the university. Except two, none of them had any medical background and have picked up medical terms and the special lexicon only on the job. The other two held medical degrees from the Soviet Union or Russia and are currently not employed as full-time doctors because of personal reasons.

Eight of the informants were employed as permanent staff in one of the hospitals, while the others work on a freelance basis while being attached to an agent who uses their services regularly. All of them attend to six to eight patients on an average on a daily basis for about $8-10$ hours. Some female interpreters worked about $4-5$ hours daily. All claimed that they found it difficult in the beginning and took time to pick up the job, some two-three months, others six months. Most of them said they worked with a dictionary at home and were creating their own glossary of commonly used medical words and phrases. Some said that when faced with a difficult and somewhat challenging situation they use Google translate on their mobile phones.

With oftentimes insufficient knowledge of medical terminology in Russian, all except the two doctors stated that they would willingly join any additional course in Russian with special emphasis on medical terms and hospital terminology. All of them said that they were on call for their patients 24 hours and answer any of their phone calls even when off duty. They provided other kind of help too, for instance for shopping and sightseeing activities as and when they could. All of them pictured a bright future for their profession and believed that the demand for Russian interpreters will keep growing. However, most of the interpreters and language workers said they were not fully satisfied with the job and felt they were being exploited while some claimed they were using this opportunity to improve their spoken skills in Russian and did not intend to work in this field for long. Most of them said they aspire to open their own healthcare brokering agencies which they see not only as the next career step in this profession, but also a potentially lucrative business.

This relates to three interpreters who for now were able to capitalize on their Russian language skills. After having worked for a few years interpreting for Russian-speaking patients, they were able to establish a professional network that allowed them to 
open their own medical brokering agencies, contracting other interpreters. As self-enterprising healthcare brokers they take care of everything from the beginning to the end putting the patient in touch with the relevant doctor at the selected hospital, completing the paper work including any medical documentation and visa applications, organizing airport pick up and accommodation. Furthermore they offer sightseeing and shopping activities for patients and their relatives if they so desire and as well as follow-up services that may be required. After having gained a high level of trust and a good reputation among patients, they become advisors to the patients while at the same time are sought after by the hospital as healthcare brokers who provide hospitals with patients. Within the hospitals they claim to have developed a good relationship with the doctors and are able to negotiate appointments and seek other favors for their patients.

However positive their outlook, a number of Russian speaking patients above 60 years of age from Central Asian countries remarked that it is their impression that within the next few years the demand for Russian language speakers would decrease since (relatively affluent) younger generations in their home countries were already quite proficient in English, a language that in the four research sites was easily understood by medical professionals. This highlights the volatility of global market conditions, speculations about potentially valuable languages (Heller and Duchêne 2016), and in the case of patient flows in transnational healthcare - shows the uncertainties that lie in attempts to capitalize on individual language skills and that of one's Russian skills in particular.

\section{CONCLUSION AND REFLECTION}

This paper demonstrates how Russian as a regional lingua franca is part of strategies of economic expansion by private healthcare providers in and around the Indian capital Delhi. Being discursively constructed as a language that for students of Russian promises employment and that eventually may lead to even bigger success as an independent healthcare broker and successful entrepreneur, within the Indian medical tourism industry, Russian assures patient flows from post-Soviet countries and as such provides an added value to healthcare services offered by each of the four hospitals. The data gathered during ethnographic fieldwork indicates that interpreters for Russian play a very prominent role in the field of medical tourism in India. The availability of language workers is a key factor which attracts patients to choose Indian hospitals not only for routine checkups, but also for major surgeries and follow-up sessions. However, both work conditions of Russian-language interpreters within hospitals and the volatility of the global healthcare market are expressions of current political-economic conditions and the globally operating neoliberal service economy in particular. Working as an interpreter for Russian-speakers requires continuous efforts in language learning and the familiarization with medical terminology in Russian; furthermore, it is described to go beyond interpreting work in medical contexts, but as a form of language work that calls for a high degree of flexibility that also incorporates activities characteristic of conventional tourism such as the provision of sightseeing and shopping trips.

Along with the ideal of flexible, self-enterprising Russian-speaking interpreters, learning Russian itself and the knowledge of key medical terminology in the language 
proved to be a challenge for a large number of them in all four hospitals. For most - and especially for those still enrolled at the university in undergraduate courses for Russian, coping with work routines meant relying on ad-hoc help in interpreting through google translate and, in addition to that, to the preparation of glossaries containing Russianlanguage medical terminology and other learning material. This connects to one notable tension between medical professionals and interpreters that surfaced during fieldwork and that to certain degrees is inherent to interpreting work within medical contexts. It relates to language proficiency and the quality of interpreting work and while all language workers are or have been university students of Russian at a certain moment in time, doctors nevertheless raised concerns regarding the accuracy of the interpreting work performed by them. Furthermore, none of the interpreters (except two) had any medical background and picked up the relevant terminology only on the job and here largely through trial and error. This conveys a rather casual approach that may lead to miscommunication and even may result in accidents and malpractice. However, to my surprise the administrative staff in the hospitals as well as the Russian-speaking patients played down the lack of medical knowledge of the language workers. This certainly leaves open a number of questions academia has to address in order to either ignore or acknowledge this as a problem. To be more precise, should we as teachers of Russian design special courses for the purpose of medical tourism. And if so, can we teach medical terminology without the relevant context? In addition to that and in the light of insufficient language skills in Russian, at what level of language acquisition can we introduce such a specialized course?

(C) Neelakshi Suryanarayan, 2017

\section{REFERENCES}

Babu, P. G., and Anjaneya Swamy, G. (2007) Medical Tourism: An analysis with special reference to India. Journal of Hospitality Application and Research, 2, 1:31-48.

Chuang, T. C., Liu, J. S., Lu, L. Y. Y., \& Lee, Y. (2014) The main paths of medical tourism: From transplantation to beautification. Tourism Management 45, 49-58.

Coulmas, F. (2005) Changing language regimes in globalizing environments. International Journal of the Sociology of Language, 175/176: 3-15.

Connell, J. (2013) Contemporary Medical Tourism: Conceptualisation, Culture and Commodification. Tourism Management, 34: 1-13.

Connell, J. (2015) Transnational health care: Global markets and local marginalisation in medical tourism. In P. Bronwyn, B. Greenhough, T. Brown, and I. Dyck (eds.) Bodies across borders: The global circulation of body parts, medical tourists and professionals. Farnham: Ashgate, 75-94.

Crooks, V. A., Turner, L., Snyder, J., Johnson, R., and Kingsbury, P. (2011) Promoting Medical Tourism to India: Messages, Images, and the Marketing of International Patient Travel. Social Science and Medicine, 72: 726-732.

Duchêne, A. (2009) Marketing, management and performance: Multilingualism as commodity in a tourism call centre. Language Policy 8: 27-50.

Duchêne, A. (2011) Néolibéralisme, inégalités sociales et plurilinguismes: l'exploitation des ressources langagières et des locuteurs. Langage \& Société, 136: 81-106. 
Harvey, D. (1989) The Condition of Postmodernity: An Enquiry into the Origins of Cultural Change. Oxford: Wiley-Blackwell.

Heller, M. (2003) Globalization, the New Economy, and the Commodification of Language and Identity. Journal of Sociolinguistics, 7 (4): 473- 492.

Heller, M. (2010) The Commodification of Language. Annual Review of Anthropology, 39: 101-114.

Heller, M., and Duchêne, A. (2012) Pride and Profit: Changing Discourses of Language, Capital and Nation State. In A. Duchêne, and M. Heller (eds.) Language in Late Capitalism: Pride and Profit. New York and London: Routledge, $1-21$.

Heller, M. and Duchêne, A. (2016) Treating language as an economic resource: Discourse, data, debates. In N. Coupland (ed.) Sociolinguistics: Theoretical Debates. New York: Cambridge University Press, $139-156$.

Jones, C. A., and Keith, L. G. (2006) Medical Tourism and Reproductive Outsourcing: The Dawning of a New Paradigm for Health-care. International Journal of Fertility and Women's Medicine, 51: $251-255$.

Kaspar, H. (2015) Private hospitals catering to foreigners underestimate interpreters' role. Hindustan Times. Retrieved from: http://www.hindustantimes.com/ht-view/private-hospitals-catering-toforeigners underestimate-interpreters-role/storyqqE4UDCcB6b0EaW8TyuOQN.html

Milstein, A., and Smith, M. (2006) America's New Refugees - Seeking Affordable Surgery Offshore. New England Journal of Medicine, 355: 1637-1640.

Muth, S. (2017) Russian as a commodity: medical tourism and the healthcare industry in post-Soviet Lithuania. In S. Muth and L. Ryazanova-Clarke (eds.) The commodification of Russian around the world (Special issue). International Journal of Bilingual Education and Bilingualism, 20(4): 404-416.

Ollapally, D. (2002) Indo-Russian Strategic Relations: New Choices and Constraints. Journal of Strategic Studies 25 (4): 135-156.

Pant, H. V. (2013) India-Russia Ties and India's Strategic Culture: Dominance of a Realist Worldview. India Review, 12 (1): 1-19.

Pavlenko, A. (2012) Commodification of Russian in post-1991 Europe. In M. Bär, A. Bonnet, H. Pavlenko, A. (2013) Language management in the Russian empire, Soviet Union, and post-Soviet countries. In R. Bayley, R. Cameron, and C. Lucas (eds.) The Oxford Handbook of Socio-linguistics. Oxford: Oxford University Press, 651-679.

Pavlenko, A. (2017) Russian-friendly: how Russian became a commodity in Europe and beyond. In S. Muth and L. Ryazanova-Clarke (eds.) The commodification of Russian around the world (Special issue). International Journal of Bilingual Education and Bilingualism, 20(4): 385403.

Tan, P, and Rubdy, R. (2008) (eds.) Language as Commodity: Global Structures and Local Marketplaces. London: Continuum.

Sahai, S. (1990) The Delhi Declaration: Cardinal of Indo-Soviet Relations. New Delhi: Mittal.

Suryanarayan, N. (2017) From Yashwant Place to Yashka: a case study of commodification of Russian in India. In S. Muth and L. Ryazanova-Clarke (eds.) The commodification of Russian around the world (Special issue). International Journal of Bilingual Education and Bilingualism, 20(4): $428-442$.

Viladrich, A., and Baron-Faust, R. (2014) Medical Tourism in Tango Paradise: The Internet Branding of Cosmetic Surgery in Argentina. Annals of Tourism Research, 45 (3): 116-131.

\section{Article history:}

Received: 20 January 2017

Revised: 20 May 2017

Accepted: 29 May 2017 


\title{
For citation:
}

Suryanarayan N. (2017). The role of Russian Language Workers in India's Health-Care Sector. Russian Journal of Linguistics, 21 (3), 515-529. doi 10.22363/2312-9182-2017-21-3-515-529.

\section{Bio Note:}

Neelakshi Suryanarayan, Phd, Professor, Head of the Department of Slavonic and Finno-Ugrian Studies, Delhi University, India. A graduate of the Peoples' Friendship University of Russia, she teaches Russian language, literature and cultural studies. She is a member of the international scientific network of ENIEDA and other professional and scientific associations, as well as the editorial boards of scientific journals, including the "The Russian Journal of Linguistics". Research interests: comparison of speech etiquette in Indian languages, Russian and English, pragmatics, commodification of the Russian language in the 21 st century. She is currently working on a project on intercultural communication, focusing on the aspects of Russian and Indian intercultural communication in the context of globalization. Contact information: e-mail: neelakshi55@yahoo.co.in

DOI: $10.22363 / 2312-9182-2017-21-3-515-529$

\section{РОЛЬ РУССКОГО ЯЗЫКА В СФЕРЕ МЕДИЦИНСКИХ УСЛУГ ИНДИИ}

\author{
Нилакши Сурьянараян \\ Делийский университет \\ Delhi University, 110007 Delhi, India
}

На протяжении последних лет можно заметить приток нового вида туристов в Индию - медицинских туристов, которые приезжают с целью получения достаточно качественного и доступного лечения и медицинских услуг. С увеличением количества пациентов из России и стран бывшего Советского Союза неуклонно растет спрос на специалистов и местных жителей со знанием русского языка. В рамках этнографической полевой работы, включающей наблюдение и интервью, в этой статье прослеживается тенденция роста использования русского языка в крупных частных больницах Дели, которые начали привлекать пациентов из бывших советских республик для оказания медицинских услуг. Цель данной статьи - представить экспериментальное исследование относительно новой сферы экономической деятельности, в которой наблюдается коммодификация русского языка. Задача состояла в исследовании того, как русский язык повышает привлекательность тех больниц, где предоставляются сопровождающие, в той или иной степени говорящие по-русски. В статье показаны конкретные условия и процессы, которые характеризуют использование русского языка в «медицинском туризме» в Индии и повышают мотивацию к изучению русского языка для этой цели. Результаты проведенного эксперимента убедительно свидетельствуют о том, что коммодификация русского языка в Индии становится ярко выраженным явлением.

Ключевые слова: медицинский туризм, Индия, коммодификация, русский язык, русскоязычные услуги

\section{История статьи:}

Дата поступления в редакцию: 20 января 2017

Дата принятия к печати: 29 мая 2017

\section{Для цитирования:}

Suryanarayan N. The role of Russian Language Workers in India's Health-Care Sector // Becmник Российского университета дружбы народов. Серия: Лингвистика. 2017. Т. 21. № 3. C. 515-529. doi 10.22363/2312-9182-2017-21-3-515-529. 


\section{Сведения об авторе:}

Нилакши Сурьянараян, кандидат филологических наук, профессор, заведующая кафедрой славянских и финно-угорских исследований Делийского университета, Индия. Выпускница РУДН. Преподает русский язык, литературу и культурологию. Является членом международного научного сообщества ENIEDA и других профессиональных и научных ассоциаций, а также редколлегий научных журналов, включая «Вестник Российского университета дружбы народов. Серия: Лингвистика». Сфера научных интересов: сопоставление речевого этикета в индийских языках, русском и английском, лингвопрагматика, коммодификация русского языка в XXI в. В настоящее время работает над проектом по вопросам межкультурного общения, уделяя особое внимание аспектам российской и индийской межкультурной коммуникации в контексте глобализации. Контактная информация: e-mail: neelakshi55@yahoo.co.in 